\title{
A Whitefly-Transmitted Golden-Yellow Mosaic Virus of Phaseolus lunatus in Puerto Rico ${ }^{1}$
}

\author{
Julio Bird, J. Enrique Pérez, Rodrigo Alconero, Nader G. Vakili, \\ and Pedro Luis Meléndez ${ }^{2}$
}

\section{INTRODUCTION}

The leguminous flora of Puerto Rico is comprised by more than 250 species. Many of these harbor viruses the identities of which are unknown or are not well established. Several virus diseases of edible legumes have been studied in the Island $(1,10,5)$.

Common bean mosaic lately has been detected in field plantings of experimental lines (2). One of the most important local legume viruses is perhaps the ubiquitous whitefly-transmitted mosaic virus of Rhynchosia minima (fig. 1). This virus is capable of inducing mild yellowing, and severe curling and stunting of different varieties and lines of beans (5). It has a wide host range and causes severe leaf curl and enations in tobacco. A golden-yellow mosaic was observed in the field recently on certain varieties of beans, (Phaseolus vulgaris), that failed to develop similar symptoms in the greenhouse when inoculated via whiteflies with the mosaic virus of R. minima.

None of the previously studied legume viruses in Puerto Rico elicited golden-yellow mosaic symptoms on $P$. vulgaris. Symptoms (figs. 2 and 3 ) corresponding to those observed on beans were found in various localities of the northwestern and north-central parts of Puerto Rico, on Phaseolus lunatus var. Haba de tocón.

The golden-yellow symptoms observed on lima beans in the field were of the type generally associated with rugaceous viruses. This mosaic was assumed therefore to be caused by a heretofore unrecognized virus transmitted in all probability by Bemisia tabaci race sidae, a whitefly which occurs on many edible and wild legumes in the Island. This race of $B$. tabaci has been shown capable of propagating four apparently distinct viruses in Puerto Rico (5). Another race of the same whitefly, i.e., $B$. tabaci race jatrophae, spreads the mosaic virus of Jatropha gossypifolia in the Island (3).

This report includes data on the transmissibility of the golden-yellow

1 Manuscript submitted to Editorial Board May.14, 1971.

2 Director, Department of Plant Pathology and Botany and Bacteriologist, respectively, Agricultural Experiment Station, Mayagüez Campus, University of Puerto Rico, Río Piedras, P.R.; Plant Pathologists, Federal Experiment Station, USDA, Mayagüez, P.R.; and Assistant Plant Pathologist, Agricultural Experiment Station, Mayagüez Campus, University of Puerto Rico, Río Piedras, P.R. 

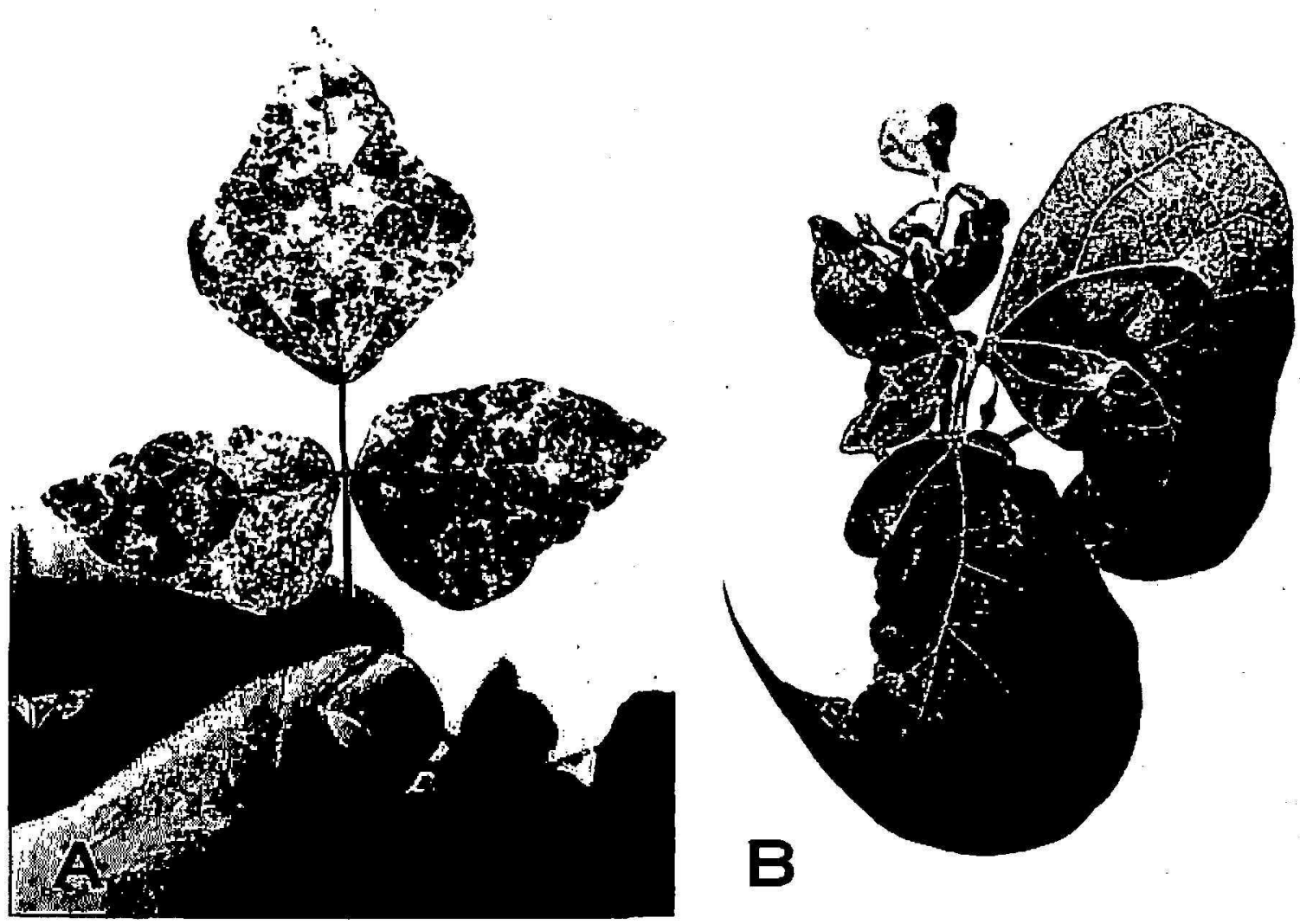

FIg. 1.-Rhynchosia minima, A, and Phaseolus vulgaris var. Caraota negra, B, affected by the whitefly-transmitted mosaic virus of $R$. minima.

mosaic virus of $P$. lunatus. Evidence is furnished indicating that the causal agent of the mosaic of $R$. minima is not closely related to the golden-yellow mosaic virus of $P$. lunatus. Data is presented proving the latter virus responsible for the field golden-yellow mosaic of beans.

\section{MATERIALS AND METHODS}

\section{MECHANICAL INOCULATIONS}

Mosaic-affected leaves of $P$. lunatus var. Haba de tocón intended for mechanical inoculation were collected from field plants or potted field plants kept in the greenhouse. These leaves were washed with fresh tap water and crushed in a mortar. The resulting sap was used to inoculate, mechanically, plants of Desmodium incanum, $P$. lunatus var. Haba de tocón, $P$. lunatus var. Henderson Bush, $P$. vulgaris var. Criolla, $P$. vulgaris var. Diablo, $P$. vulgaris var. Jamaica, Vigna repens, and $V$. sinensis var. Blackeye. Prior to inoculation, plants were dusted with carborundum ( $600 \mathrm{mesh})$. A total of 30 plants of each species were inoculated, without chemical adjuvants, in three trials, at the rate of 10 plants per trial. Suitable noninoculated controls, one for each plant inoculated, were maintained in a separate greenhouse. 


\section{INOCULATIONS VIA WHITEFLIES}

Cylindrical, lumite screen-topped, plexiglass cages of various diameters and heights were employed in the transmission studies (4). Simple plastic tubular collecting devices of the sucking type were used to collect and transfer the whiteflies. Test plants were kept, up to the moment of colonization, in small glass-topped cages with lumite screen sides, similar to those employed in previous studies $(3,4)$. Virus-free stock cultures of the whitefly B. tabaci race sidae were maintained on caged plants of Sida carpinifolia. The insects were obtained originally from Chamaesyce hypericifolia. For virus acquisition, the aviruliferous whiteflies were released (mass numbers) on potted, caged-source plants and allowed an acquisition feeding period of 24 hours. Because, once released inside the cages, the great majority of the insects migrated to the lumite screen top which is usually well illuminated, a cylindrical hood made of black velveteen was fitted over the cage to a height that coincided with the uppermost level of the foliage. This measure insured almost immediate migration of the whiteflies from the top of the cage to the foliage of the test plant. In well illuminated places, collection of whiteflies was facilitated by placing a black matte cloth behind the colonized source plant. This resulted in improved contrast and aided greatly in collecting whiteflies from the golden-yellow mosaicaffected leaves. Viruliferous whiteflies, generally 50 individuals per plant, were allowed an inoculation feeding period of 24 hours on the test plants. They then were blown away from the inoculated plant with a jet of air or killed by spraying with nicotine sulfate. Most of the fabaceous hosts were inoculated at a tender stage, just before emergence of the first trifoliate. As a rule, other test plants were inoculated at the six-leaf stage. Sritable uninoculated controls were also included in this trial.

\section{RECIPROCAL INOCULATIONS}

For this trial a set of 10 healthy $P$. lunatus var. Haba de tocón plants and another set comprised by 10 healthy plants of $R$. minima were crossinoculated via whiteflies with the mosaic virus of $R$. minima and the golden mosaic of $P$. lunatus. The viruliferous condition of each batch of whiteflies was verified by inoculation of the respective primary host. This particular test was repeated twice. A total of 10 plants of each species was used in each test.

\section{CROSS PROTECTION STUDY}

For the study on protection, eight plants of the lima bean variety Henderson Bush (susceptible to both viruses) were inoculated via whiteflies-50 viruliferous individuals per plant - with the mosaic virus of $R$. minima. All the plants thus treated developed systemic but mild symptoms consisting 
of irregularly distributed angular chlorotic blotches accompanied by slight distortion of the laminae of the leaves. Four of the eight plants thus infected were challenged with the $P$. lunatus virus which also was inoculated via whiteflies at the rate of $\mathbf{5 0}$ individuals per plant. The remaining four plants were kept in cages as controls.

\section{RECOVERY OF THE GOLDEN MOSAIC VIRUS OF $P$. lunalus FROM BEAN PLANTINGS}

A number of branches with young turgid leaves bearing golden-yellow mosaic symptoms were collected from two bean fields, respectively, in the north-central and northwestern parts of the Island and transported to the greenhouse at Río Piedras. On arrival, the freshest looking branches were washed with cool tap water and dried by shaking a few times. Then the basal end of each branch was driven about $1 \frac{1}{2}$ inches into deep storage dishes filled to their brims with water-drenched sand. The excess water in each storage dish was decanted to consolidate the sand and thus provide adequate anchorage to the branch. The complete unit, i.e., branch and storage dish, was then covered with an appropriate cylindrical cage and mass-colonized with virus-free whiteflies. The insects were allowed to remain on the virus source plants for 24 hours. After this time, the whiteflies were released in batches of approximately 100 insects per plant, on caged plants of $P$. vulgaris var. Diablo, $P$. vulgaris var. Contender, $P$. vulgaris var. Galana, $P$. vulgaris P.I.287536, $P$. vulgaris var. Caraota Negra, $P$. vulgaris var. Green Refugee, and $P$. lunatus var. Ramos. A parallel test was conducted using whiteflies carrying the golden-yellow mosaic virus of $P$. lunatus for comparative purposes.

\section{EXPERIMENTAL RESULTS}

MECHANICAL INOCULATIONS

None of the plants inoculated by mechanical means developed symptoms of disease after the end of $11 / 2$ months. The uninoculated controls also remained healthy. The results of these inoculation trials were taken as an indication that the causal agent probably was insect-borne under natural conditions.

\section{TRANSMISSION VIA THE WHITEFLY $B$. tabaci RACE sidae}

Adult whiteflies, as well as pupae, of $B$. tabaci had been observed on the foliage of mosaic-affected $P$. lunatus plants growing in various barrios in northern Puerto Rico. Adult whiteflies (B. tabaci race sidae $)^{3}$ collected from $P$. lunatus were found to feed and breed well on $C$. hypericifolia and

${ }^{3}$ Pupae were kindly identified by Dr. Louise M. Russell, Insect Identification and Parasite Introduction Research Branch, ARS, USDA, Washington, D. C. 
TABLe 1.-Range of the Phaseolus lunatus virus and of its whilefly vector (Bemisia tabaci race sidae), as well as symploms induced by the former, on a series of selected hosts inoculated in the greenhouse

\begin{tabular}{|c|c|c|c|c|}
\hline \multirow{2}{*}{ Plant species treated } & \multirow{2}{*}{$\begin{array}{l}\text { Number of } \\
\text { plants } \\
\text { inoculated } \\
\text { successfully } \\
\text { over total } \\
\text { number of } \\
\text { plants tested1 }\end{array}$} & \multicolumn{2}{|c|}{$\begin{array}{c}\text { Colonization } \\
(+ \text { or }-)^{2}\end{array}$} & \multirow{2}{*}{$\begin{array}{l}\text { Symptoms on } \\
\text { test plant }\end{array}$} \\
\hline & & $\begin{array}{l}\text { Feed- } \\
\text { ing }\end{array}$ & $\underset{\substack{\text { Breed- } \\
\text { ing }}}{ }$ & \\
\hline Ipomoea quinquefolia & $0 / 50$ & + & + & None \\
\hline Jacquemontia tamnifolia & $0 / 30$ & + & + & None \\
\hline Phaseolus lalhyroides & $8 / 40$ & + & + & GYV, GYM \\
\hline Phaseolus lunatus var. Haba de tocón & $39 / 42$ & + & + & GYV, GYM \\
\hline Phaseolus lunatus var. Henderson & $18 / 24$ & + & + & GYV, GYM \\
\hline Phaseolus vulgaris var. Criolla & $37 / 40$ & + & + & GYV, GYM \\
\hline Phaseolus vulgaris var. Diablo & $30 / 40$ & + & + & GYV, GYM \\
\hline Phaseolus vulgaris var. Harvest King & $30 / 30$ & + & + & GYV, GYM \\
\hline Nicotiana tabacum var. Virginia 12 & $0 / 20$ & + & + & None \\
\hline Rhynchosia minima & $0 / 40$ & + & + & None \\
\hline Sida carpinifolia & $0 / 60$ & + & + & None \\
\hline Sida rhombifolia & $0 / 50$ & + & + & None \\
\hline Vigna sinensis var. Black & $0 / 20$ & + & - & None \\
\hline Vigna sinensis var. Blackeye & $0 / 20$ & + & - & None \\
\hline
\end{tabular}

150 insects per plant.

${ }^{2}+$ denotes that whiteflies fed or bred well; - denotes that whiteflies failed to feed or breed.

${ }^{3}$ GYV-Golden-yellow veins.

GYM-Golden-yellow mosaic.

S. carpinifolia. In a series of preliminary trials the causal agent was repeatedly transmitted via $B$. tabaci race sidae from diseased to healthy plants of $P$. lunatus var. Haba de tocón. Further inoculation tests werc carried out using not only $P$. lunatus var. Haba de tocón but other local lima bean and bean varieties and the primary hosts of some of the well known Puerto Rican whitefly-transmitted viruses. The first symptoms on $P$. lunatus and beans appeared, sometimes, as early as 3 to 4 days after the plants were exposed to viruliferous whiteflies and consisted of small thin yellow blotches, sometimes star shaped, along the veinlets (fig. 4). After a day or two, in the case of developing leaves, more of these blotches appeared. At the end of about 8 days most of the veinlets had become goldenyellow in color giving the leaf a reticulated appearance, the veinal system yellow, backgrounded by the dark green color of the leaf. In general, subsequent trifoliates developed systemic golden-yellow mosaic. However, the leaves of some plants only developed golden-yellow vein symptoms (fig. 5). Table 1 shows the results of this limited host range study. Bean plants developed symptoms not at all similar to those normally seen on plants 


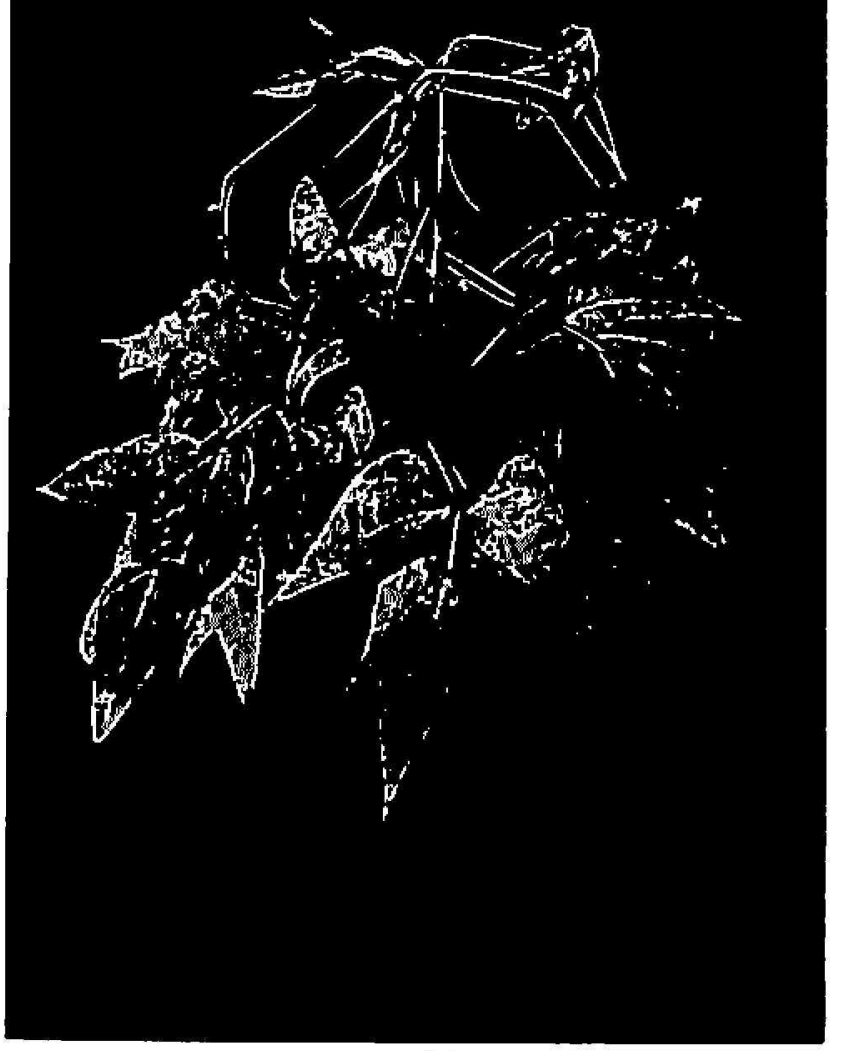

$2 \mathrm{~A}$

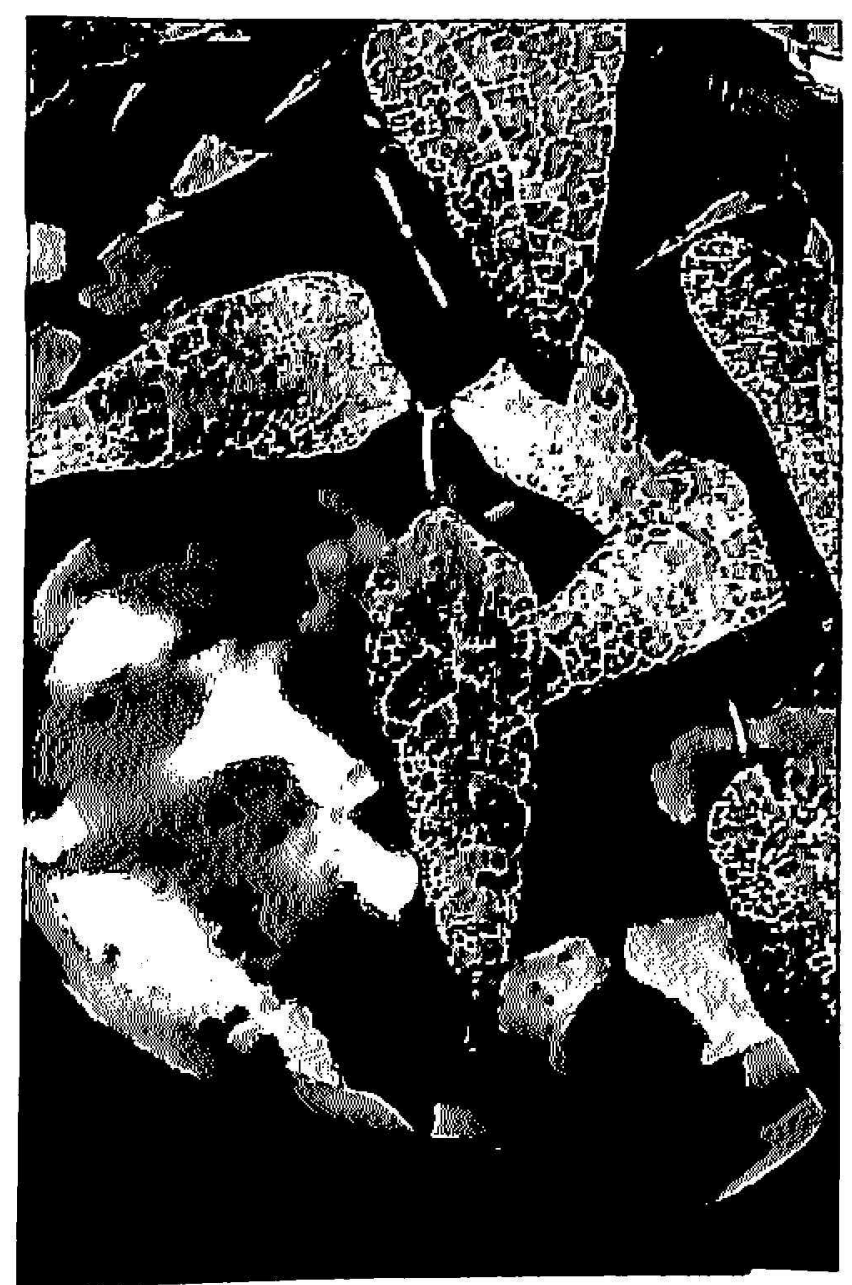

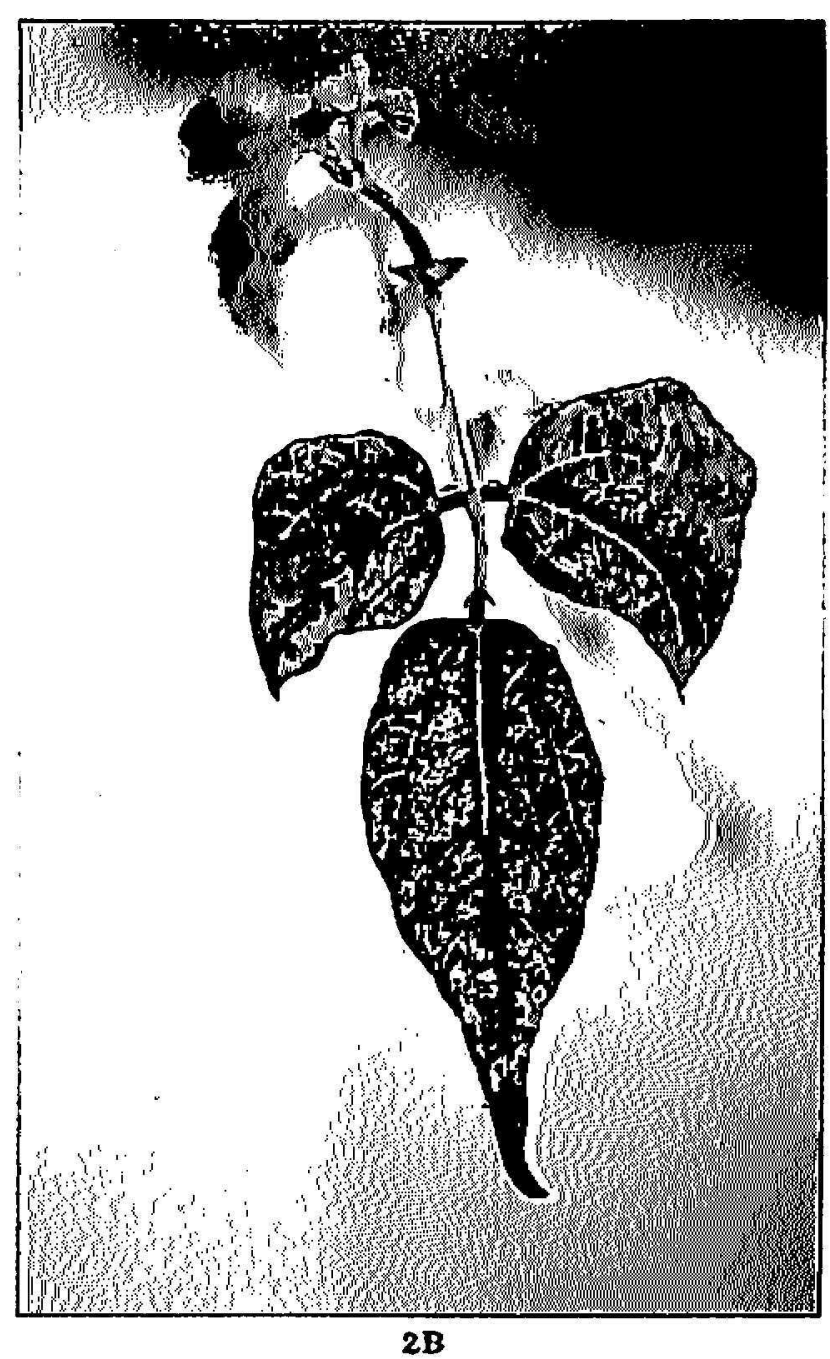

Fig. 2.-Phaseolus lunatus var. Haba de tocón plant, $A$, and trifoliate leaf of a Diablo variety bean plant, B, affected by the Puerto Rican golden-yellow mosaic virus of $P$. lunatus.

Fia. 3.-Close-up of golden-yellow mosaic-affected leaves of Phaseolus lunatus var. Haba de tocón. 
affected by the $R$. minima mosaic. The $P$. lunatus virus generally provokes a golden-yellow mosaic and also induces some curling and distortion of the leaves. The latter symptoms are not as severe as those induced on the foliage of beans by the Rhynchosia mosaic virus.

\section{RECIPROCAL INOCULATION TESTS}

None of the $P$. lunatus var. Haba de tocón plants subjected to whiteflies carrying the $R$. minima mosaic virus developed symptoms of disease. Similarly, none of the $R$. minima plants treated with whiteflies carrying the golden-yellow mosaic virus of $P$. lunatus developed symptoms of mosaic.

\section{CROSS PROTECTION STUDY}

Plants of the bush lima bean variety Henderson, mildly but systemicallyinfected with the mosaic virus of $R$. minima, developed extremely severe golden-yellow mosaic and leaf distortion symptoms 8 days after being

TABLE 2.-Symptoms incited on a series of leguminous hosts, separately inoculated via the whilefly Bemisia tabaci race sidae, by two field isolates of bean golden-yellow mosaic virus and by one isolate of the golden-yellow mosaic virus of Phaseolus lunatus

\begin{tabular}{|c|c|c|c|c|c|c|}
\hline \multirow{3}{*}{ Host } & \multicolumn{6}{|c|}{ Isolate, number of plants infected over total number treated and symptoms 1} \\
\hline & \multicolumn{2}{|c|}{$\begin{array}{l}\text { Bean golden-yellow } \\
\text { mosaic virus, Mayaguez } \\
\text { isolate }\end{array}$} & \multicolumn{2}{|c|}{$\begin{array}{c}\text { Bean golden-yellow } \\
\text { mosaic virus, Barceloneta } \\
\text { isolate }\end{array}$} & \multicolumn{2}{|c|}{$\begin{array}{l}\text { P. Lunaius golden-yellow } \\
\text { mosaic virus, Vega Baja } \\
\text { isolate }\end{array}$} \\
\hline & $\left|\begin{array}{c}\text { Number } \\
\text { infected } \\
\text { over } \\
\text { total } \\
\text { number } \\
\text { treated }\end{array}\right|$ & Symptoms & $\begin{array}{c}\text { Number } \\
\text { infected } \\
\text { over } \\
\text { total } \\
\text { number } \\
\text { treated }\end{array}$ & Symptoms & $\left|\begin{array}{c}\text { Number } \\
\text { infected } \\
\text { over } \\
\text { total } \\
\text { number } \\
\text { treated }\end{array}\right|$ & Symptoms \\
\hline $\begin{array}{l}\text { P. vulgaris var. Di- } \\
\text { ablo }\end{array}$ & $4 / 6$ & GYV, GYM & $6 / 6$ & GYV, GYM & $3 / 6$ & GYV, GYM \\
\hline $\begin{array}{l}P . \text { vulgaris var. Con- } \\
\text { tender }\end{array}$ & $5 / 6$ & GYV, GYM & $4 / 5$ & GYV, GYM & $5 / 6$ & GYV, GYM \\
\hline $\begin{array}{l}P \text { vulgaris var. } \\
\text { Galana }\end{array}$ & $3 / 6$ & GYV, GYM & $2 / 5$ & GYV, GYM & $4 / 6$ & GYV, GYM \\
\hline P. vulgaris P.I. 287536 & $2 / 6$ & GYV, GYM & $4 / 5$ & GYV, GYM & $2 / 6$ & GYV, GYM \\
\hline $\begin{array}{l}P \text { vulgaris var. } \\
\text { Caraota Negra }\end{array}$ & $2 / 6$ & GYV, GYM & $5 / 6$ & GYV, GYM & $3 / 6$ & GYV, GYM \\
\hline $\begin{array}{l}P \text { vulgaris var. } \\
\text { Green Refugee }\end{array}$ & $3 / 6$ & GYV, GYM & $2 / 6$ & GYV, GYM & $3 / 6$ & GYV, GYM \\
\hline $\begin{array}{l}P . \quad \text { lunatus var. } \\
\text { Ramos }\end{array}$ & $1 / 6$ & GYV, GYM & $5 / 5$ & GYV, GYM & $2 / 6$ & GYV, GYM \\
\hline
\end{tabular}

\footnotetext{
1 GYV-Golden-yellow veins.
} GYM-Golden-yellow mosaic. 
superinoculated via whiteflies with the $P$. lunatus mosaic virus. The goldenyellow reticulation of the veins also became evident on the inoculated plants. The control plants, i.e., those infected only with the mosaic virus of R. minima, remained with mild but systemic infection.

\section{RECOVERY OF THE GOLDEN-YELLOW MOSAIC VIRUS OF $P$. lunatus} FROM BEAN PLANTINGS

Table 2 shows the results of the parallel tests carried out in an attempt to verify whether or not the field golden-yellow mosaic virus of beans is related to the golden-yellow mosaic virus of $P$. lunatus. Symptoms that developed on the various plants inoculated via whiteflies with the field isolates were identical with those incited on the same hosts by the known isolate of the golden-yellow mosaic virus of $P$. lunatus.

\section{DISCUSSION}

The evidence derived from inoculation of selected hosts, as well as from reciprocal inoculation and cross protection studies described herein, indicate rather strongly that the Puerto Rican whitefly-transmitted viruses of $R$. minima and $P$. lunatus are not closely related, although they have several characteristics in common. The incubation period of the $P$. lunatus virus on fast growing hosts (beans and lima beans) can be extremely short; 72 hours from inoculation to onset of primary symptoms. The same cannot be stated about the incubation of the mosaic virus of $R$. minima on fast growing hosts. Bean and susceptible lima bean plants normally develop primary symptoms 8 to 14 days after inoculation. Moreover, the primary symptoms, angular chlorotic blotches prompted by the Rhynchosia virus, were not similar to those provoked on the same hosts by the P. lunatus virus. Furthermore, secondary and late symptoms of both diseases on beans and lima beans were quite different. The $P$. lunatus virus induced golden-yellow symptoms on susceptible hosts with great consistency, in contrast with the light yellow symptoms incited, in general, by the virus of $R$. minima. $R$. minima, which is the primary or main host of the Rhynchosia virus, failed to become infected when inoculated with the $P$. lunatus virus via $B$. tabaci race sidae. Similar results were obtained on inoculating $P$. lunatus var. Haba de tocón plants with the Rhynchosia virus via the samc race of whitefly. Both viruses affected lima bean plants of the variety Henderson Bush causing different symptoms. Also, Rhynchosia virusaffected lima bean plants of this last variety developed severe symptoms of disease (superimposed infection) when inoculated via whiteflies with the $P$. lunatus virus. The distinct golden-yellow mosaic characteristically provoked by the $P$. lunatus virus appeared clearly on plants thus challenged.

The results obtained from inoculation of selected hosts indicated that the $P$. lunatus virus is not closely related to the Puerto Rican whitefly-trans- 
mitted viruses of Ipomoea quinquefolia, Jacquemontia tamnifolia, $R$. minima and S. carpinifolia. No attempts were made to inoculate plants of $J$. gossypifolia with the mosaic virus of $P$. lunatus. The writers believe the causal agent of this last disease is not related to the whitefly-transmitted mosaic virus of $J$. gossypifolia. The Jatropha virus is transmitted by $B$. tabaci race jatrophae, a whitefly mostly restricted in its range to hosts of the genus Jatropha. Attempts made to breed and feed this last race of the whitefly $B$. tabaci on leguminous hosts have not been successful. Perhaps even more important is that attempts made in Puerto Rico to infect beans with the Jatropha virus via the two known races of $B$. tabaci have not been successful.

That field isolates of the golden-yellow mosaic virus of beans provoked the same symptoms on a series of selected hosts as those elicited by the golden-yellow mosaic virus of $P$. lunatus is more than a fair indication of close relationship. They are possibly identical or at least closely related strains.

The symptoms of the Puerto Rican golden-yellow mosaic of beans and lima beans are remarkably similar to those reported by Costa (6) for the golden mosaic of beans in the State of Sao Paulo, Brazil. They also resemble those described by Gámez $(8,9)$ for the yellow mottle (moteado amarillo) of beans in El Salvador. Whether or not the causal agents of these diseases are one and the same remains to be determined.

Two whitefly-transmitted legume viruses are known thus far to occur in Puerto Rico. Both cause serious and well distributed diseases of beans. Further research will be directed towards determining the general host range, vector virus relationships, etc. of the golden-yellow mosaic virus of $P$. lunatus. Perhaps more information on the relationships of rugaceous viruses could be gained through electron microscopy. Knowledge on particle morphology of whitefly transmitted viruses is scant (7). More research on this aspect might bring rewarding results from both basic and practical standpoints.

\section{SUMMARY}

A golden-yellow mosaic virus of Phaseolus lunatus was detected recently in Puerto Rico. The virus was transmitted by the whitefly Bemisia tabaci race sidae. It causes a golden-yellow mosaic of beans. It was isolated from

Fic. 4.- Early symptoms elicited on lima bean, A, and bean, B, leaflets by the golden-yellow mosaic virus of $P$. lunatus.

Fig. 5.-Golden-yellow vein symptoms provoked by the $P$. lunatus virus on lima bean plant of the variety Ramos. 
bean plantings located in the northwestern and north-central parts of Puerto Rico. Available evidence indicates that the $P$. lunatus virus is not related, at least closely, to the Puerto Rican whitefly-transmitted mosaic virus of Rhynchosia minima. Symptoms induced by the $P$. lunatus virus are remarkably similar to those elicited by the Brazilian golden mosaic and the Salvadoran yellow mottle viruses of beans.

\section{RESUMEN}

Recientemente se descubrió en Puerto Rico un mosaico dorado en Phaseolus lunatus. El virus lo transmite la mosca blanca Bemisia tabaci raza sidae y afecta la habichuela común, causándole un mosaico dorado. El virus se aisló de siembras comerciales de habichuelas localizadas en las secciones norte-central y noroeste de la Isla. Todo parece indicar que dicho virus no está relacionado, por lo menos estrechamente, con el que causa el mosaico de Rhynchosia minima. Los síntomas provocados por el virus de $P$. lunatus son muy parecidos a los del mosaico dorado del Brasil y los del moteado amarillo, que afecta la habichuela en El Salvador.

\section{LITERATURE CITED}

1. Adsuar, J., A mosaic disease of cowpea, Vigna sinensis Savi, in Puerto Rico, J. Agr. Univ. P.R. 48(3) : 264, 1964.

2. Alconero, R., Unpublished data.

3. Bird, J., A whitefly-transmitted mosaic of Jatropha gossypifolia, Agr. Exp. Sta., Univ. P.R., Tech. Paper 22, May 1957.

4. Bird, J., Infectious chlorosis of Sida carpinifolia in Puerto Rico, Agr. Exp. Sta., Univ. P.R., Tech. Paper 29, Oct. 1958.

5. Bird, J., and Sánchez, J., Whitefly-transmitted viruses in Puerto Rico, J. Agr. Univ. P.R. 55(4) : 461-7, 1971.

6. Costa, A. S., Three whitefly-transmitted virus diseases of beans in Sao Paulo, Brazil, FAO Plant Prot. Bull. 13 (6) : 121-30, 1965.

7. Costa, A. S., White flies as virus vectors. In: Virus Vectors and Vegetation, Ed. K. Maramorosch, John Wiley \& Sons, New York, N.Y., pp. 95-119, 1969.

8. Gámez, R., Estudios preliminares sobre virus del frijol transmitidos por moscas blancas (Aleyrodidae) en El Salvador. En: Programa Cooperativo Centroamericano para el Mejoramiento de Cultivos Alimenticios, XVa Reunión Anual, El Salvador, 1969.

9. - - El Virus del Moteado Amarillo del Frijol-Plantas Hospederas y Efecto en Producción. En: Programa Cooperativo Centroamericano para el Mejoramiento de Cultivos Alimenticios, XVIa Reunión Anual, Guatemala, 1970.

10. Pérez, J. E. and Cortés-Monllor, A., A mosaic virus of cowpea from Puerto Rico, Pl. Dis. Reptr. 54: 212-6, 1970. 